\title{
Machine milking of dairy goats during lactation: udder anatomy, milking characteristics, and blood concentrations of oxytocin and prolactin
}

\author{
BY RUPERT M. BRUCKMAIER, CHANTAL RITTER, DIETER SCHAMS* \\ AND JÜRG W. BLUM \\ Institut für Tierzucht der Universität Bern, CH-3012 Bern, Schweiz \\ * Institut für Physiologie der Technischen Universität München, \\ D-85354 Freising-Weihenstephan, Deutschland
}

\section{(Received 20 September 1993 and accepted for publication 21 March 1994)}

\begin{abstract}
Summary. Forty-four goats were milked and milk flow recorded without or with $1 \mathrm{~min}$ manual prestimulation in early, mid and late lactation. Ultrasound measurements of cross sections of the whole mammary gland were performed in a water bath. In additional experiments with 15 goats, milk flow was recorded and frequent blood samples were taken for the determination of oxytocin and prolactin concentrations. Milk yield increased from the first to the third lactation and decreased markedly during the course of lactation. Average and peak milk flow rates were closely related to the actual milk yield. The ultrasound cisternal area was $27 \cdot 4 \pm 1.5 \%$ of the entire udder half cross section. Milking characteristics were scarcely different without or with prestimulation, although oxytocin was released within $30 \mathrm{~s}$ after the start of prestimulation, whereas oxytocin concentrations without prestimulation increased only after the start of milking. Concentrations of prolactin were higher during July and August than in April, and increased similarly with or without prestimulation during milking. In contrast to dairy cows, prestimulation and an opportune release of oxytocin during milking does not significantly influence the course of milk flow in goats, and this is probably because large amounts of cisternal milk allow milk ejection to be induced only after the start of milking without causing bimodal or otherwise reduced milk flow.
\end{abstract}

Alveolar milk ejection, elicited by oxytocin (OT) released in response to teat stimulation, has been repeatedly demonstrated in dairy cows (Schams et al. 1984; Gorewit \& Gassman, 1985; Mayer et al. 1991). Furthermore, the importance of an opportune OT release and induction of milk ejection before the start of machine milking for fast and complete milk removal was demonstrated in cows (Mayer et al. 1984). In goats, the secretion of OT during hand milking has been demonstrated (Folley \& Knaggs, 1966; Mosdøl et al. 1981; Seckl \& Lightman, 1988), and milk ejection due to manual stimulation of the udder and in response to exogenous OT has also been demonstrated (Mosdøl et al. 1981 ; Bruckmaier \& Blum, 1992). However, continuously recorded milk flow rates and simultaneous profiles of $\mathrm{OT}$ and prolactin (PRL) have not previously been investigated in dairy goats. The goal of this work was to test the hypothesis that manual prestimulation is important for OT and PRL release and for satisfactory milking characteristics of goats during the course of 
lactation. In addition, milk removal was evaluated in connection with the anatomy of cisternal cavities relative to gland tissue of goat mammary glands measured by ultrasound imaging.

\section{MATERIALS AND METHODS}

\section{Animals, feeding and milking}

During these experiments, dairy goats of the herd of the Swiss Federal Station for Animal Production, Posieux, were milked twice daily at their usual milking times, 07.00 and 16.00. All animals belonged to the Swiss Saanen breed and were in their first to sixth lactation. The animals were given a ration of $3 \mathrm{~kg}$ dry matter consisting of $40 \%$ hay and $60 \%$ concentrates, and were milked at a $48 \mathrm{kPa}$ vacuum, using a Westfalia goat milking cluster (no. 7036-2600-040, Westfalia Separator AG, Oelde, Germany) comprising Westfalia liners (no. 7036-2902-030). Pulsation ratio and rate were set at 60:40 and 90 pulses/min respectively, using a Westfalia Stimopuls P pulsator. At routine milkings, the milking cluster was attached after a short dry cleaning of teats and gland with wood wool. Experimental milking included either a 1 min manual prestimulation, i.e. cleaning and massage of teat and gland, or no pretreatment at all.

\section{Milk flow and ultrasound measurements}

In the first experiment 44 animals were milked in three series during 2 week periods in months 1-3, 4-6 and 7-9 of lactation. During months 1-6, all goats were non-pregnant, whereas most were pregnant in months 7-9. Milk flow rate was continuously recorded using a strain gauge system as described previously (Bruckmaier et al. 1992). During each experimental series the goats were milked on 4 succeeding days (morning and evening) with 1 min manual prestimulation and on $4 \mathrm{~d}$ without udder preparation. A total of 2052 milk flow curves were recorded. Total, main and stripping yield and time, and average and peak flow rate and time to reach peak flow rate were evaluated. Peak flow rate was defined as the maximal flow reached and maintained for at least $10 \mathrm{~s}$.

The udders of the same 44 goats were visualized by ultrasound once during mid lactation (months 4-6) without any udder preparation shortly before evening milking. Cross sections of the entire udder halves including cisternal cavities were examined from a caudal direction in a water bath as described by Bruckmaier \& Blum (1992). The method has been shown to be suitable for measurements of cisternal size in dairy cows and closely correlated with corresponding frozen sections and corrosion casts (Bruckmaier et al. 1994). Absolute and relative cisternal size were estimated by measuring the section areas of cavities and gland tissue, and the position of both udder components relative to the whole mammary gland was classified. In addition, the actual volume of the total udder size was estimated immediately before evening milking by dipping the entire udder into a water-filled bucket and measuring the water displacement.

\section{Hormone concentration measurements}

In a second experiment, five goats were milked during April and ten goats during late July and early August, all non-pregnant, and milk flow was recorded while blood samples were taken for the determination of OT and PRL concentrations. Goats were in their second to fifth month of lactation. Indwelling catheters were inserted into the right jugular vein after morning milking, and remained there for the entire $3 \mathrm{~d}$ experimental period. Blood samples were taken during the succeeding evening 
milking in order to familiarize the animals with the experimental procedure. As milking characteristics and hormone profiles during this first milking were not different from those in the other milkings, these results were included in the statistical evaluation. During the four succeeding milkings, each goat was milked without and with 1 min prestimulation at one evening and one morning milking. Blood samples were taken at $-3,-1,-0.5,0,0.5,1,1.5$ and $2 \mathrm{~min}$, taking the start of milking as 0 , and from then on every minute until 2 min after the end of milking. A total of 75 profiles were evaluated. Concentrations of OT (Schams, 1983) and PRL (Bruckmaier et al. 1992) were both determined radioimmunologically. The suitability of the ovine PRL radioimmunoassay for the determination of caprine PRL was confirmed experimentally. Serial plasma dilutions paralleled the standard curve.

\section{Statistical evaluation}

All results in text and tables are given as means \pm SEM. Analysis of variance was performed employing the General Linear Model of the SAS program, release 6.07 (SAS, 1993). The model used was $Y=A_{i}+B_{j}+C_{k}+D_{l}+e_{i j k l}$, where $Y$ is the measured value, $A$ the effect of the animal, $B$ the effect of stimulation, $C$ the effect of time of day (a.m. or p.m.), $D$ the effect of stage of lactation and $e$ the residual error. The interactions between stimulation and time of day, and between stimulation and stage of lactation were found not to be significant. Significant differences $(P<0 \cdot 05)$ were tested with Tukey's studentized range test. Changes during the course of milking were tested for significance $(P<0.05)$ by the paired $t$ test using the UNIVARIATE procedure. Pearson's correlation coefficients between different variables were calculated employing the CORR procedure.

\section{RESULTS}

\section{Milking characteristics}

Mean daily milk yield at experimental milkings increased $(P<0.05)$ from the first to the third lactation $(2 \cdot 50 \pm 0 \cdot 06,3 \cdot 46 \pm 0.06$ and $3 \cdot 88 \pm 0 \cdot 06 \mathrm{~kg}$ for goats in their first, second and third lactation respectively), and then remained similar in older goats.

Total and main milk yields were $40 \%$ lower at afternoon than at morning milking $(P<0.05)$, owing to different milking intervals $(9$ and $15 \mathrm{~h})$, and decreased during the course of lactation $(P<0.05$; Table 1, Fig. 1). Despite a longer milking interval, the hourly secretion rate tended to be higher during the night than during the day, although this was not significant $(P=0 \cdot 15)$. Total and main milk yields were similar with and without stimulation in early and mid lactation, and were higher with stimulation in late lactation $(P<0.05)$. Stripping yield (Table 1) was lowest in early lactation and was slightly higher in mid and late lactation. Total and main milking times (Table 1) generally increased from early to mid lactation and fell again in late lactation. Stripping time remained relatively constant during the course of lactation. None of the 2052 milk flow curves during milking with or without prestimulation was bimodal or showed other signs of delayed milk ejection after removal of cisternal milk. Two types of milk flow curves were observed: curves that reached their maximum in $<10 \mathrm{~s}$ (Fig. $1 a$ ) and curves whose maximum was in the form of a plateau (Fig. 1b). Both milk flow types remained stable and characteristic for each animal during the entire lactation, 61 and $39 \%$ being milk flow types 1 and 2 respectively. Both average and peak flow rates were generally $10-20 \%$ lower at afternoon than at morning milking (results not shown, $P<0.05$ ), and decreased markedly during the course of lactation, independent of milk flow type $(P<0.05$; 


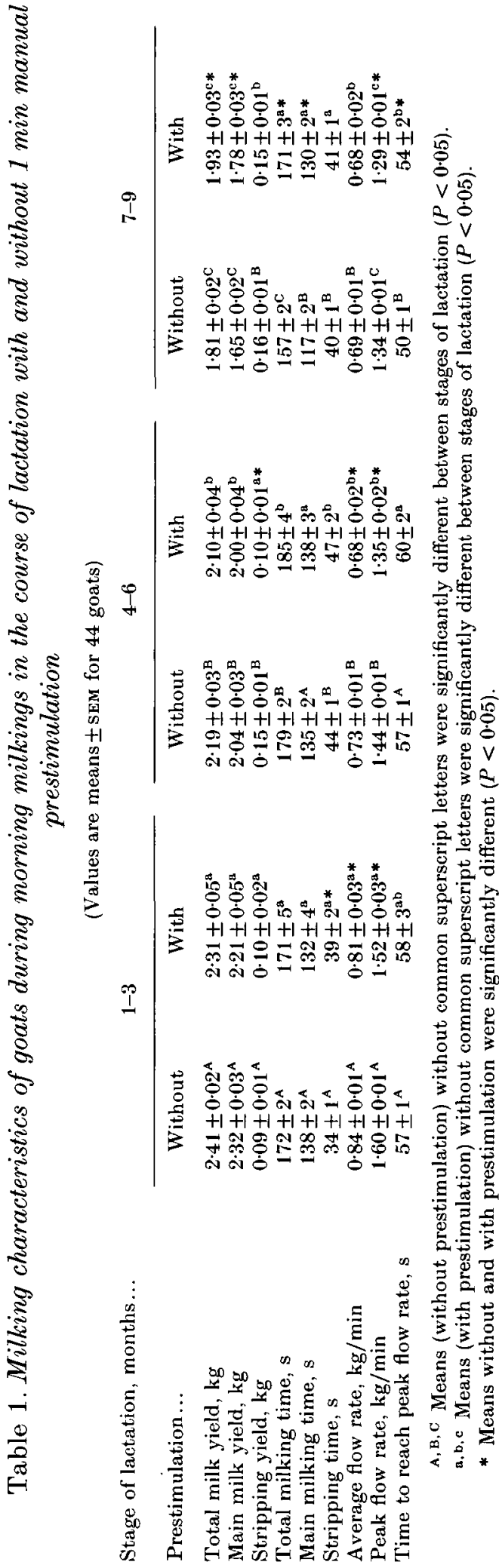




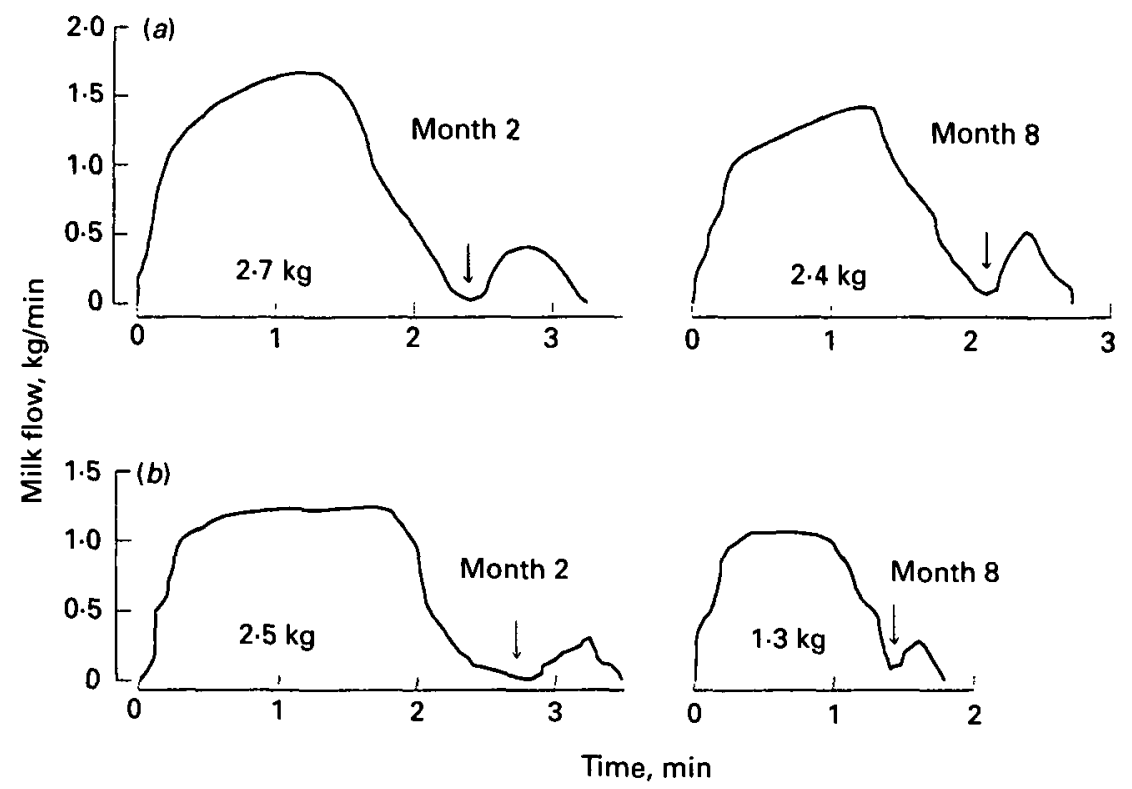

Fig. 1. Milk flow rates of $(a)$ one goat with peak milk flow maximum (type 1$)$ and $(b)$ one goat with plateau milk flow maximum (type 2) during morning milkings without prestimulation in months 2 and 8 of lactation. Time 0 , start of milking; $\downarrow$, start of stripping. Milk yields $(\mathrm{kg})$ are shown.

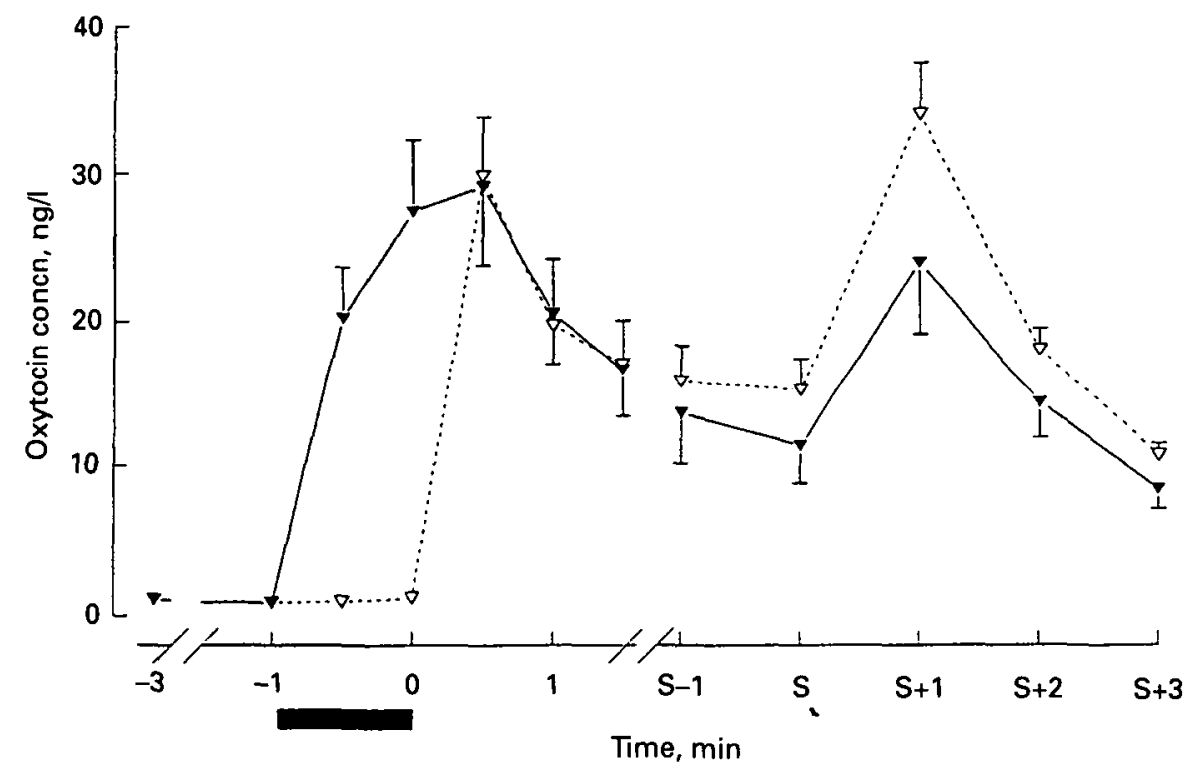

Fig. 2. Concentrations of oxytocin before milking, during milking, and during and after stripping with $(\nabla-\nabla)$ and without $(\nabla \ldots-\nabla) 1$ min prestimulation. Time 0 , start of milking; , stimulation; $\mathrm{S}$, start of stripping. Values are means with SEM indicated by vertical bars; for clarity only half the range is shown.

Table 1, Fig. 1). Peak flow rate was slightly lower during milking with than without stimulation in mid and late lactation $(P<0.05)$. Changes of milk flow rates for both milk flow types were obviously mainly dependent on the actual milk yield, and correlation coefficients $(r)$ between total milk yield and average and peak flow rates were 0.70 and 0.52 respectively $(P<0.05)$. Time to reach peak flow rate (Table 1) 


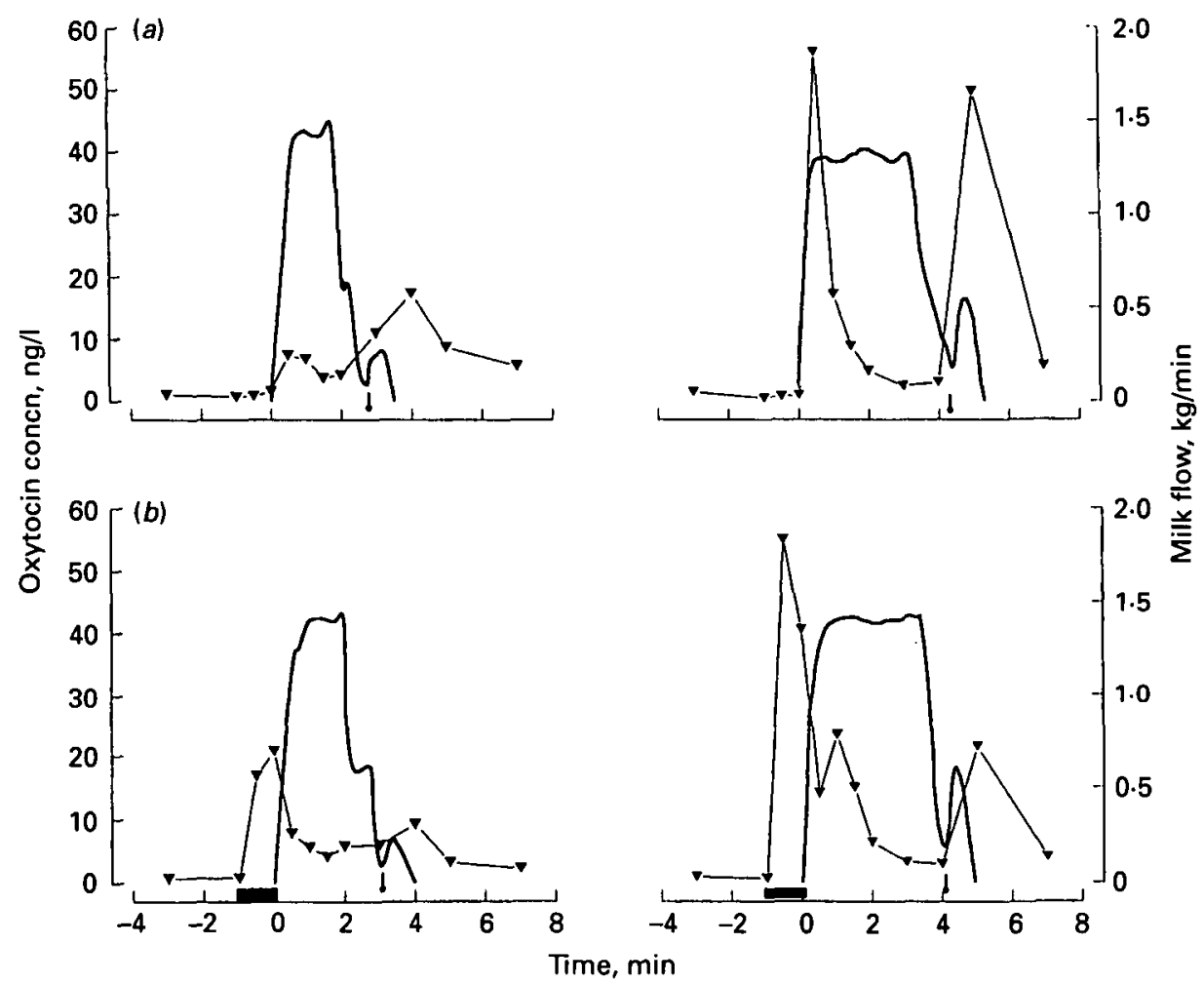

Fig. 3. Milk flow rates (-) and corresponding oxytocin concentrations ( $\boldsymbol{\nabla}$ ) of two individual goats $(a)$ without and $(b)$ with 1 min prestimulation

tended to be prolonged by stimulation, but this difference was only significant at morning milking in late lactation.

\section{Udder anatomy}

Ultrasound cross sectional areas of the 88 cisterns of mammary gland halves ranged from 1900 to $8630 \mathrm{~mm}^{2}$ with mean values of $4330 \pm 250 \mathrm{~mm}^{2}$ in the left and $4010 \pm 250 \mathrm{~mm}^{2}$ in the right half of the udder. Cisternal areas of the two corresponding udder halves were correlated $(r=0.70 ; P<0.05)$, and together accounted for $27 \cdot 4 \pm 1.5 \%$ of the entire udder half cross sections. While there was no correlation between cisternal area size and milk yield and milk flow traits and between tissue area size and milk yield $(r<0 \cdot 2 ; P>0 \cdot 05)$, goats with milk flow type 2 (Fig. $1 b)$ had larger cisterns $\left(4820 \pm 430 \mathrm{~mm}^{2} ; 31 \%\right.$ of the whole udder) than goats with milk flow type 1 (Fig. $1 a ; 3740 \pm 270 \mathrm{~mm}^{2} ; 24 \%$ of the whole udder; $P<0 \cdot 05$ ). In all animals, the cistern was located in the lower caudal part of the udder with the teat located at the bottom, whereas the mammary tissue was primarily located dorso-cranially. The total udder volume, estimated by water displacement, was $2.42 \pm 0.07$ l. Total milk yield was closely correlated with udder volume $(r=0.75 ; P<0.05)$, i.e. total milk yield $(\mathrm{kg})=0.13 \pm 0.65 \times$ udder volume $(\mathrm{l})$.

\section{Oxytocin concentrations and milking characteristics}

As shown in Figs 2 and 3, premilking baseline concentrations of OT were similarly low in all animals. During milking without stimulation (Figs 2 and $3 a$ ), OT increased markedly $(P<0.05)$ within $30 \mathrm{~s}$ after the start of milking and decreased again during 
Table 2. Plasma prolactin concentrations during milking without and with prestimulation during experimental periods in April and July-August

(Values are means $\pm \mathrm{SEM}$ in $\mu \mathrm{g} / \mathrm{l}$ )

\begin{tabular}{|c|c|c|c|c|c|c|}
\hline \multirow[b]{2}{*}{ Period } & \multirow[b]{2}{*}{ Prestimulation } & \multirow[b]{2}{*}{$n$} & \multicolumn{4}{|c|}{ Sampling time } \\
\hline & & & $S M-1 \min$ & SM & $\mathrm{EM}$ & $\mathrm{EM}+2 \min$ \\
\hline April & $\begin{array}{l}\text { No } \\
\text { Yes }\end{array}$ & 5 & $\begin{array}{l}185 \pm 18^{* \mathrm{a}} \\
209 \pm 22^{* \mathrm{a}}\end{array}$ & $\begin{array}{l}198 \pm 18^{\mathrm{a}} \\
225 \pm 21^{\mathrm{a}}\end{array}$ & $\begin{array}{l}366 \pm 31^{\mathrm{b}} \\
495 \pm 36^{\mathrm{b}}\end{array}$ & $\begin{array}{l}684 \pm 60^{c} \\
832 \pm 98^{\mathrm{c}}\end{array}$ \\
\hline July-August & $\begin{array}{l}\text { No } \\
\text { Yes }\end{array}$ & 10 & $\begin{array}{l}558 \pm 39^{* a} \\
487 \pm 43^{* a}\end{array}$ & $\begin{array}{l}541 \pm 36^{\mathrm{a}} \\
505+48^{\mathrm{a}}\end{array}$ & $\begin{array}{l}636 \pm 43^{\mathrm{b}} \\
743 \pm 68^{\mathrm{b}}\end{array}$ & $\begin{array}{l}727 \pm 55^{\circ} \\
752+83^{\mathrm{b}}\end{array}$ \\
\hline
\end{tabular}

SM, start of milking; EM, end of milking.

* Corresponding premilking concentrations were significantly different between experimental periods $(P<0.05)$.

a. b.e Means without common superseript letters within experimental period and treatment were significantly different $(P<0.05)$.

continued milking. If manual prestimulation was applied (Figs 2 and $3 b$ ), concentrations of OT increased within $30 \mathrm{~s}$ after the start of stimulation and started to decrease after the milking cluster was attached. Although OT concentrations decreased during milking, in both treatments they remained higher than premilking (baseline) concentrations $(P<0.05)$. During stripping (Figs 2 and 3), OT concentrations increased again $(P<0.05)$ within 1 min to concentrations similar to those at the start of milking and decreased immediately when milking was stopped.

As already shown, milking characteristics were not significantly different during milking with or without stimulation (Fig. $3 a, b$ ), although the increase of OT concentrations occurred either before or only after the start of milking, respectively.

\section{Prolactin concentrations}

Premilking concentrations of PRL (Table 2) were higher $(P<0.05)$ in July-August than in April. During the course of milking, PRL increased markedly and increased further until 2 min after milking was stopped (last blood sample). The PRL patterns were not significantly different between milking with and without stimulation.

\section{DISCUSSION}

In all experiments, milking was performed at a pulsation ratio and pulsation rate shown to be optimal for milking speed and udder health using similar milking equipment for goats of a comparable performance level ( $\mathrm{Lu}$ et al. 1991). The differences in total and main milk yields and corresponding milking times between morning and evening milking were mainly due to different milking intervals. However, despite the longer milking interval, the hourly secretion rate was slightly higher during the night, possibly because of fewer disturbances.

In early and mid lactation, prestimulation had no beneficial effect on total and main milk yields, whereas both milk yields were slightly higher with than without stimulation in late lactation. In contrast to cows, where prestimulation was shown to reduce milking time and to enhance milk flow rate (Mayer et al. 1984), the higher milk yield in goats was partly associated with prolonged milking time. Milk flow rates were only slightly changed, and tended to be decreased rather than increased by prestimulation. However, during milking with prestimulation, OT was released immediately after the start of stimulation, i.e. much earlier than without prestimulation. It was therefore surprising that animals did not react to 
prestimulation. The course of milk flow was not influenced by prestimulation, although OT was released immediately after the start of stimulation, so opportune release of OT does not seem to be very important for milk removal in the goat, even though alveolar milk ejection in response to stimulation or exogenous OT has been demonstrated (Mosdøl et al. 1981; Bruckmaier \& Blum, 1992).

Ultrasonographic measurements showed large cisternal cavities, so clearly large amounts of cisternal milk can be stored in goats relative to the total size of the mammary gland. The cisternal milk fraction was shown to be 5-10\% in cows (Bruckmaier et al. 1993, 1994) and to be closely correlated with cisternal areas derived from ultrasound cross sections (Bruckmaier et al. 1994). The cisternal milk fraction is obviously much larger in goats than in dairy cows. Peaker \& Blatchford (1988) also found the alveolar milk fraction in goats to be very small compared with the cisternal milk fraction. It is therefore likely that between the start of milking and milk ejection following milking-induced OT release, milk flow is maintained by milk present in the cistern.

Average and peak milk flow rates were lower during evening than during morning milking and were markedly decreasing during the course of lactation, thus demonstrating the dependence of milk yield and milk flow. This may be related to different intracisternal pressure levels. It was previously demonstrated that high milk yields were associated with high pressure increments in goats (Mosdøl et al. 1981). In dairy cows, intracisternal pressure decreased with decreasing milk yield during the course of lactation (Bruckmaier, 1988; Mayer et al. 1991), whereas peak milk flow rate remained almost constant (Bruckmaier, 1988). Goats whose milk flow reached and maintained its maximum shortly after the start of milking (type 2) had larger cisterns than goats whose milk flow steadily increased until the udder was empty (type 1). An increase of intramammary pressure during milk ejection may have had some enhancing effect on milk flow in udders with small cisterns, whereas in larger cisterns the relative increase of intramammary pressure would be small and therefore have no discernible effect on the milk flow curve. It could also be speculated that the steadily increasing milk flow is to some extent due to relaxation of smooth muscle tone.

In none of the premilking blood samples were elevated OT concentrations detected before tactile stimulation was applied to the udder. Thus, as previously shown in dairy cows, there was no evidence for conditioned OT release induced by the events usually preceding milking (Mayer et al. 1984, 1991). Similarly, McNeilly (1972) found occasionally conditioned O'T release before suckling, but never before hand milking. However, after the start of prestimulation or milking, OT was released within $30 \mathrm{~s}$. This agrees with Seckl \& Lightman (1988), who found OT release in goats within 1 min after the start of milking. Interestingly, and in contrast to most dairy cows (Mayer et al. 1984), OT concentration in all goats decreased again after the first release at the start of milking. Only in response to the manipulations during stripping was an additional release of $\mathrm{O}^{\prime} \mathrm{T}$ observed. It is possible that manipulations during prestimulation, starting machine milking and stripping are necessary for distinct OT release, whereas normal machine milking has a smaller stimulatory effect on OT release in goats. During hand milking, OT was mostly released at the start of milking (Mosdøl et al. 1981).

In contrast to OT, which was mostly released at the start of milking and during stripping, PRL increased continuously during the course of milking. The dramatic increase in circulating PRL caused by the milking stimulus and a seasonal increase of baseline concentrations from spring to summer have been demonstrated previously 
(Bryant et al. 1968; Hart, 1975). As in cows (Schams et al. 1972), artificial inhibition of PRL release in response to milking during an already established lactation did not affect the milk yield of goats (Hart, 1973; Forsyth \& Lee, 1993). The importance of the tremendous increase of PRL during milking during established lactation in goats is unclear, because milk production was shown to be independent of the PRL concentration, at least as long as PRL concentrations are not totally depressed by antagonistic drug treatment (Knight et al. 1990; Forsyth \& Lee, 1993).

In conclusion, for practical milking of dairy goats, prestimulation other than udder cleaning and premilking does not seem to be necessary except during late stages of lactation. Even in late lactation, the prolonged milking time if goats are prestimulated is of little economic interest because there is only a small increase in milk yield.

We are indebted to the Swiss Federal Research Station of Animal Production, CH-1725 Posieux for providing us with the animals and we thank Dr R. Daccord and Mr K. Zbinden for excellent cooperation during the experiments. Part of the milking equipment was donated by the Westfalia Separator AG.

\section{REFERENCES}

Bruck Ma er, R. M. 1988 [Oxytocin Release, Intramammary Pressure and Milk Production in the Cow in Relation to Stage of Lactation and Effect of the Adrenergic System.] Thesis, Technische Universität München, Weihenstephan, Germany

BruckMaler, R. M. \& BLUM, J. W. 1992 B-mode ultrasonography of mammary glands of cows, goats and sheep during $\alpha$ - and $\beta$-adrenergic agonist and oxytocin administration. Journal of Dairy Research 59 151-159

Bruckmaigr, R. M., Rothenanger, E. \& Blum, J. W. 1994 Measurement of mammary gland cistern size and determination of the cisternal milk fraction in dairy cows. Milchwissenschaft In press

Bruckmaier, R. M., Schams, D. \& Blum, J. W. 1992 Aetiology of disturbed milk ejection in parturient primiparous cows. Journal of Dairy Research $59479-489$

Bruckmaier, R. M., Schams, D. \& Blum, J. W. 1993 Milk removal in familiar and unfamiliar surroundings: concentrations of oxytocin, prolactin, cortisol and $\beta$-endorphin. Journal of Dairy Research $60449-456$

Bryant, G. D., Greenwood, F. C. \& Linzell, J. L. 1968 Plasma prolactin levels in the goat: physiological and experimental modification. Journal of Endocrinology $40 \mathrm{iv}-\mathrm{v}$

Folley, S. J. \& KNaggs, G. S. 1966 Milk-ejection activity (oxytocin) in the external jugular vein blood of the cow, goat and sow, in relation to the stimulus of milking or suckling. Journal of Endocrinology 34197-214

Forsyth, I. A. \& LEE, P. D. 1993 Bromocriptine treatment of periparturient goats: long-term suppression of prolactin and lack of effect on lactation. Journal of Dairy Research 60 307-317

Gorewit, R. C. \& Gassman, K. B. 1985 Effects of duration of udder stimulation on milking dynamies and oxytocin release. Journal of Dairy Science 68 1813-1818

HART, I. C. 1973 Effect of 2-bromo- $\alpha$-ergocryptine on milk yield and the level of prolactin and growth hormone in the blood of the goat at milking. Journal of Endocrinology 57 179-180

HART, I. C. 1975 Concentrations of prolactin in serial blood samples from goats before, during and after milking throughout lactation. Journal of Endocrinology 64 305-312

Knight, C. H., Foran, D. \& Wilde, C. J. 1990 Interactions between autocrine and endocrine control of milk yicld : thrice-daily milking of bromocriptine-treated goats. Journal of Reproduction and Feritity 5 Abstr. no. 30

Lu, C. D., Potrototra, M. J. \& Loetz, E. R. 1991 Influence of vacuum level, pulsation ratio and rate on milking performance and udder health in dairy goats. Small Ruminant Research 5 1-8

MCNeilly, A. S. 1972 The blood levels of oxytocin during suckling and hand-milking in the goat with some observations on the pattern of hormone release. Journal of Endocrinology 52 177-188

Mayer, H., Bruckmaier, R. M. \& Schams, D. 1991 Lactational changes in oxytocin release, intramammary pressure and milking characteristics in dairy cows. Journal of Dairy Research 58 159-169

Mayer, H., Schams, D., Worstorff, H. \& Prokopp, A. 1984 Secretion of oxytocin and milk removal as affected by milking cows with and without manual stimulation. Journal of Endocrinology 103 355-361

Mospol, G. Sjanstad, O. V. \& Blom, A. K. 1981 Plasma concentrations of oxytocin and intramammary pressure in goats during manual stimulation of the udder and hand-milking. Journal of Endocrinology 90 159-166

Peaker, M. \& Blatchford, D. R. 1988 Distribution of milk in the goat mammary gland and its relation to the rate and control of milk secretion. Journal of Dairy Research 55 41-48

SAS 1993 SAS User's Guide: Statistics. Cary, NC: SAS Institute 
Schams, D. 1983 Oxytocin determination by radioimmunoassay. III. Improvement to subpicogram sensitivity and application to blood levels in cyclic cattle. Acta Endocrinologica 103 180-183

Schams, D., Mayer, H., Prokopp, A. \& Worstorff, H. 1984 Oxytocin secretion during milking in dairy cows with regard to the variation and importance of a threshold level for milk removal. Journal of Endocrinology $102337-343$

Schams, D., Reinhardt, V. \& KaRg, H. 1972 Effects of 2 -Br- $\alpha$-ergocriptine on plasma prolactin level during parturition and onset of lactation in cows. Experientia $28697-699$

Seckl, J. R. \& Lightman, S. L. 1988 Potentiation of lactation-induced oxytocin secretion by intracerebroventricular oxytocin in the conscious goat. Journal of Endocrinology 116 273-277 